\title{
N-Acetylcysteine Amide (NACA) Reduces Cell Death after Oxidative Stress in a Porcine Embryonic Kidney Cell Line
}

\author{
Torkil Benterud ${ }^{1,2^{*}}$, Sophia Manueldas ${ }^{1 *}$, Svante Norgren ${ }^{3}$, Rønnaug Solberg1,4, \\ Ola Didrik Saugstad', Lars O. Baumbusch ${ }^{1}$
}

\footnotetext{
${ }^{1}$ Department of Pediatric Research, Division of Pediatric and Adolescent Medicine, Oslo University Hospital Rikshospitalet, Oslo, Norway

${ }^{2}$ Department of Pediatrics, Vestre Viken Hospital Trust, Drammen, Norway

${ }^{3}$ Department of Women's and Children's Health, Division of Paediatric Endocrinology, Karolinska Institutet, Stockholm, Sweden ${ }^{4}$ Department of Pediatrics, Vestfold Hospital Trust, Tønsberg, Norway

Email: "Torkil.Benterud@rr-research.no
}

How to cite this paper: Benterud, T., Manueldas, S., Norgren, S., Solberg, R., Saugstad, O.D. and Baumbusch, L.O. (2017) N-Acetylcysteine Amide (NACA) Reduces Cell Death after Oxidative Stress in a Porcine Embryonic Kidney Cell Line. J. Biomedical Science and Engineering, 10, 31-36. https://doi.org/10.4236/jbise.2017.102004

Received: December 28, 2016

Accepted: January 21, 2017

Published: January 24, 2017

Copyright (c) 2017 by authors and Scientific Research Publishing Inc. This work is licensed under the Creative Commons Attribution International License (CC BY 4.0).

http://creativecommons.org/licenses/by/4.0/

\begin{abstract}
Introduction: Oxidative stress may have detrimental effects on different structures of the cells, such as the DNA. Recently, we have published a study demonstrating that N-Acetylcysteine amide (NACA) displayed anti-inflammatory properties on the brain after exposure to oxidative stress in an established neonatal piglet model, imitating perinatal asphyxia. As different clinical studies have shown an association between the severity of hypoxic-ischemic encephalopathy and damage of the kidneys, we investigated a possible protective effect of NACA against $\mathrm{H}_{2} \mathrm{O}_{2}$-induced oxidative stress using a porcine epithelial-like embryonic kidney cell line (EFN-R). Objective: To investigate a potential protective effect of NACA on cells of a porcine embryonic kidney cell line exposed to $\mathrm{H}_{2} \mathrm{O}_{2}$. Methods: We subjected the cells to different concentrations of $\mathrm{H}_{2} \mathrm{O}_{2}$ for variable time periods, seeking the optimal dose-response for the experiments. Based on the results of these investigations, we exposed the cells to $100 \mu \mathrm{Mol}$ of $\mathrm{H}_{2} \mathrm{O}_{2}$ and/or $750 \mu \mathrm{M}$ of NACA for 24 hours. Some of the cells would receive NACA either one hour before or one hour after exposure to $\mathrm{H}_{2} \mathrm{O}_{2}$. Results: The viability of the investigated EFN-R cells revealed that both, the group treated with NACA before exposure to $\mathrm{H}_{2} \mathrm{O}_{2}$ and the group treated with NACA after exposure to $\mathrm{H}_{2} \mathrm{O}_{2}$, exhibited significantly higher cell viability compared to the $\mathrm{H}_{2} \mathrm{O}_{2}$ group ( $<<0.001$ and $\mathrm{p}<0.01$, respectively). Discussion: The increased viability of the cells may indicate that NACA could play an important role in reducing oxidative stress. Taking the results from our previous study into consideration, our findings may streng-
\end{abstract}

*The marked authors should be considered as joint first authors. 
then the theory that NACA may have organ protective properties for neonates exposed to oxidative stress.

\section{Keywords}

N-Acetylcysteine Amide (NACA), Cell Lines, Oxidative Stress

\section{Introduction}

Reactive oxygen species (ROS) are important in different processes of the organism, including cell-signaling [1]. However, during oxidative stress, too much ROS is produced, which may have detrimental effects on different structures of the cells. ROS play a role as a mediator of apoptosis and may induce damage to the DNA. One important member of $\mathrm{ROS}$ is $\mathrm{H}_{2} \mathrm{O}_{2}$, which may be harmful to the DNA and leads to cell injury.

Recently, we have published a study demonstrating that NACA displayed antiinflammatory properties after exposure to oxidative stress in an established neonatal piglet model, imitating perinatal asphyxia [2]. Our piglet model has been established for many years and several authors have shown a significant increase in markers of oxidative stress after the inflicted asphyxia [3]. As different clinical studies have shown an association between the severity of hypoxic-ischemic encephalopathy and damage of the kidneys [4] [5], we decided to investigate possible protective effects of NACA using the porcine epithelial-like embryonic kidney cell line EFN-R exposed to $\mathrm{H}_{2} \mathrm{O}_{2}$. Previous studies have shown that NACA may reduce the injury in epithelial kidney cells exposed to toxic doses of the antibiotic Gentamycin and the contrast agent Iohexol [6] [7]. Prior to the experiments with NACA, dose-response investigations of $\mathrm{H}_{2} \mathrm{O}_{2}$ were conducted to estimate the appropriate dose for the treatment of cells of a cell line.

\section{Objective}

To investigate a potential protective effect of NACA on cells of an embryonic kidney cell line exposed to $\mathrm{H}_{2} \mathrm{O}_{2}$.

\section{Methods}

Cell culture: The porcine epithelial-like embryonic kidney cell line EFN-R (catalogue number CCLV-RIE 86) was generated and provided by courtesy of the Friedrich-Loeffler Institute, Federal Research, Institute for Animal Health, Greifswald-Insel Riems, Germany.

EFN-R cells were grown using Dulbecco's modified eagle's medium (DMEM) (Sigma-Aldrich, St. Louis, Missouri, USA), 10\% fetal bovine serum (FBS) and $1 \%$ streptomycin (Sigma-Aldrich, St. Louis, Missouri, USA). The cells were incubated in a cell chamber at $36.8^{\circ} \mathrm{C}$ and $5 \% \mathrm{CO}_{2}$. Cells were cultured when they were approximately $80 \%$ confluent. The confluence describes the percentage of 
cells in growth. For subculturing, the cells were washed with PBS, trypsinated and incubated in the cell chamber for 3 minutes. Cells were then centrifuged at $3000 \mathrm{rpm}$ for 3 minutes, and the pellet was dissolved in fresh cell medium.

A Bürker-chamber was used to calculate cell numbers. $100 \mu$ of cell suspension together with $900 \mu \mathrm{l}$ tryptan blue solutions (Life Technology, UK) was added onto a Bürker-chamber glass plate and covered with a slide and placed under a microscope. The amount of cells was counted in minimum of five squares, and the average value of number of cells per square was calculated. The cells were counted only on the top and the left edge of each square, to avoid cells be counted twice. The desired amount of cells was adjusted and transferred to plates for further experiments.

MTT: For measuring the number of viable cells the MTT-test was conducted. The MTT-test is a reliable, simple, and established method to measure cytotoxicity, proliferation, and activation in cell lines [8]. The MTT (3,4,5 dimethylthiazol-2,5 diphenyl tetrazolium, Sigma-Aldrich, St. Louis, Missouri, USA) viability assay is based on the ability of mitochondrial dehydrogenase enzymes in living cells to convert MTT to a purple formazan precipitate. These mitochondrial succinate dehydrogenases may reflect the number of viable cells present. The resulting crystals are subsequently dissolved using dimethyl sulfoxide (DMSO) and the optical density of each well is measured using a multiscan acent plate reader (Thermo Electron Corporation, Waltham, Massachusetts, USA). Cells were exposed to $\mathrm{H}_{2} \mathrm{O}_{2}$ for 1 hour. After incubation, the medium was removed and $200 \mu \mathrm{l}$ MTT was added and incubated for 1 hour. MTT was removed and $100 \mu \mathrm{l}$ of DMSO was added. The cells in the control group received DMEM.

Cell line experiments. The EFN-R cells were used as model system for stress experiments. 150.000 cells were seeded in each well in a 12-wells plate. The cells were starved for 24 hours and the confluent cells were treated with $\mathrm{H}_{2} \mathrm{O}_{2}$ for various incubation time and concentrations. In the dose-response investigation of $\mathrm{H}_{2} \mathrm{O}_{2}$ we sought the preferable dose of $\mathrm{H}_{2} \mathrm{O}_{2}$ to be used in the main experiment. The cell plate was divided into four groups with triplicates, and each group was treated with different concentrations of $\mathrm{H}_{2} \mathrm{O}_{2}$ (Figure 1).

Statistics. The analyses were performed using SPSS software v21 (SPSS Inc. Chicago, Illinois, USA). The data were analyzed using the Kruskal-Wallis test and Mann-Whitney $U$ test for variables with non-normal distributions. For normal distributions, Student $t$-test and ANOVA were performed.

\section{Results}

EFN-R cells, exposed to $\mathrm{H}_{2} \mathrm{O}_{2}$ at various concentrations and for different time periods, revealed a decline in cell viability with increasing concentrations and exposure time.

Based on the results of the experiment described above, we decided to subject the EFN-R cells to $100 \mu \mathrm{Mol}$ of $\mathrm{H}_{2} \mathrm{O}_{2}$ and/or $750 \mu \mathrm{M}$ of NACA for 24 hours.

Our second experiment revealed that cells exposed to NACA 1 hour after treatment with $\mathrm{H}_{2} \mathrm{O}_{2}$ had a lower mortality than cells subjected to $\mathrm{H}_{2} \mathrm{O}_{2}$ alone, 
$\mathrm{p}<0.01$. Also the group subjected to NACA 1 hour before exposure to $\mathrm{H}_{2} \mathrm{O}_{2}$ displayed significantly higher viability 24 hours later $(\mathrm{p}<0.001)$ (Figure 2$)$.

\section{Discussion}

In this study, our aim was to investigate a possible protective effect of NACA to a porcine embryonic kidney cell line exposed to oxidative stress by $\mathrm{H}_{2} \mathrm{O}_{2}$ treatment.

The dose of $750 \mu \mathrm{M}$ of NACA was decided because of previous reports demonstrated that NACA was protective to neural cells exposed to oxidative stress induced by Glutamate [9].

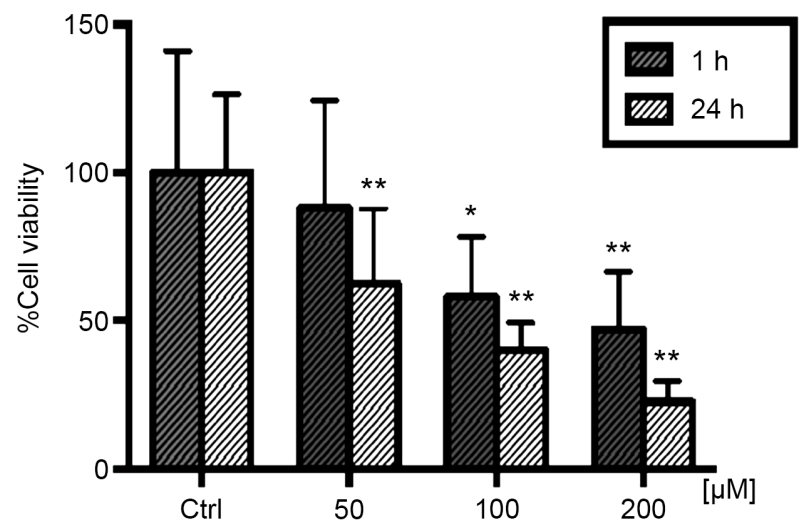

Figure 1. Effect of different concentration of $\mathrm{H}_{2} \mathrm{O}_{2}$ at different time points, measured by the MTT-assay. Cells were treated with different concentrations $(50,100$, and $200 \mu \mathrm{Mol})$ of $\mathrm{H}_{2} \mathrm{O}_{2}$ and incubated either for $1(n=8)$ or $24(\mathrm{n}=9)$ hours. Viable cells were assessed by MTT-assay, presented in percentage compared to control for the representative time point. Values represent means \pm standard deviation (SD). Statistically different values of ${ }^{*} \mathrm{p}<0.05,{ }^{* *} \mathrm{p}<0.01$ were calculated with t-test and compared to cells without $\mathrm{H}_{2} \mathrm{O}_{2}$ treatment (control).

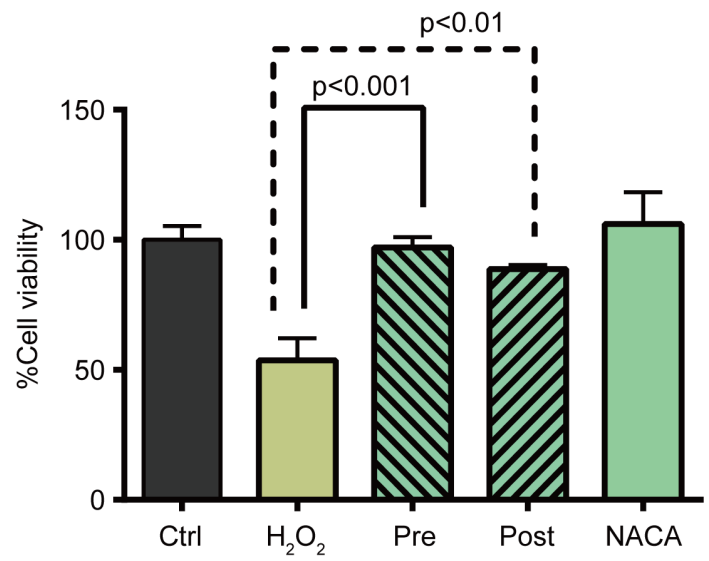

Figure 2. Cells exposed to $\mathrm{H}_{2} \mathrm{O}_{2}$ had a significantly higher mortality rate compared to the control group not exposed to $\mathrm{H}_{2} \mathrm{O}_{2}(\mathrm{p}<0.001)$. The NACA group was exposed to NACA, but not $\mathrm{H}_{2} \mathrm{O}_{2}$. Evaluation of the viability of the EFN-R cells revealed that both the group treated with NACA before exposure to $\mathrm{H}_{2} \mathrm{O}_{2}$ (Pre) and the group treated with NACA after exposure to $\mathrm{H}_{2} \mathrm{O}_{2}$ (Post), exhibited significantly higher cell viability compared with the $\mathrm{H}_{2} \mathrm{O}_{2}$ group ( $\mathrm{p}<0.001$ and $\mathrm{p}<0.01$, respectively). 
Even though several studies have shown advantageous outcomes of NACA in different cell cultures subjected to oxidative stress [10] [11], we are, to our knowledge, the first who confirm the positive effects using a porcine epithelial-like embryonic kidney cell line.

\section{Conclusions}

The augmented viability of the EFN-R cells may indicate that NACA could play a crucial role when reducing oxidative stress.

Taking the results from our previous study into consideration, we suggest that NACA may have organ protective properties for neonates exposed to perinatal oxidative stress.

We underscore that our results are based on experiments on isolated cells and more studies should be accomplished before considering transferring them into a clinical trial.

\section{Conflict of Interests}

There are no conflicts of interests to declare.

\section{References}

[1] Devasagayam, T.P., Tilak, J.C., Boloor, K.K., Sane, K.S., Ghaskadbi, S.S. and Lele, R.D. (2004) Free Radicals and Antioxidants in Human Health: Current Status and Future Prospects. The Journal of the Association of Physicians of India, 52, 794-804.

[2] Benterud, T., Ystgaard, M.B., Manueldas, S., Pankratov, L., Alfaro-Cervello, C., Florholmen, G., Ahmed, M.S., Sandvik, L., Norgren, S., Bjoras, M., et al. (2016) NAcetylcysteine Amide Exerts Possible Neuroprotective Effects in Newborn Pigs after Perinatal Asphyxia. Neonatology, 111, 12-21. https://doi.org/10.1159/000447255

[3] Osterholt, H.C., Dannevig, I., Wyckoff, M.H., Liao, J., Akgul, Y., Ramgopal, M., Mija, D.S., Cheong, N., Longoria, C., Mahendroo, M., et al. (2012) Antioxidant Protects against Increases in Low Molecular Weight Hyaluronan and Inflammation in Asphyxiated Newborn Pigs Resuscitated with 100\% Oxygen. PloS ONE, 7, e38839. https://doi.org/10.1371/journal.pone.0038839

[4] Gupta, B.D., Sharma, P., Bagla, J., Parakh, M. and Soni, J.P. (2005) Renal Failure in Asphyxiated Neonates. Indian Pediatrics, 42, 928-934.

[5] Alaro, D., Bashir, A., Musoke, R. and Wanaiana, L. (2014) Prevalence and Outcomes of Acute Kidney Injury in Term Neonates with Perinatal Asphyxia. African Health Sciences, 14, 682-688. https://doi.org/10.4314/ahs.v14i3.26

[6] Gong, X., Celsi, G., Carlsson, K. and Norgren, S. (2012) Protective Effects of NAcetylcysteine Amide (NACA) on Gentamicin-Induced Apoptosis in LLC-PK1 Cells. Renal Failure, 34, 487-494. https://doi.org/10.3109/0886022X.2012.655684

[7] Gong, X., Celsi, G., Carlsson, K., Norgren, S. and Chen, M. (2010) N-Acetylcysteine Amide Protects Renal Proximal Tubular Epithelial Cells against Iohexol-Induced Apoptosis by Blocking p38 MAPK and iNOS Signaling. American Journal of Nephrology, 31, 178-188. https://doi.org/10.1159/000268161

[8] Mosmann, T. (1983) Rapid Colorimetric Assay for Cellular Growth and Survival: Application to Proliferation and Cytotoxicity Assays. Journal of Immunological Methods, 65, 55-63. https://doi.org/10.1016/0022-1759(83)90303-4

[9] Penugonda, S., Mare, S., Goldstein, G., Banks, W.A. and Ercal, N. (2005) Effects of 
N-Acetylcysteine Amide (NACA), a Novel Thiol Antioxidant against GlutamateInduced Cytotoxicity in Neuronal Cell Line PC12. Brain Research, 1056, 132-138. https://doi.org/10.1016/j.brainres.2005.07.032

[10] Sunitha, K., Hemshekhar, M., Thushara, R.M., Santhosh, M.S., Yariswamy, M., Kemparaju, K. and Girish, K.S. (2013) N-Acetylcysteine Amide: A Derivative to Fulfill the Promises of N-Acetylcysteine. Free Radical Research, 47, 357-367. https://doi.org/10.3109/10715762.2013.781595

[11] Tobwala, S., Khayyat, A., Fan, W. and Ercal, N. (2015) Comparative Evaluation of $\mathrm{N}$-Acetylcysteine and N-Acetylcysteineamide in Acetaminophen-Induced Hepatotoxicity in Human Hepatoma HepaRG Cells. Experimental Biology and Medicine (Maywood, N), 240, 261-272. https://doi.org/10.1177/1535370214549520

Submit or recommend next manuscript to SCIRP and we will provide best service for you:

Accepting pre-submission inquiries through Email, Facebook, LinkedIn, Twitter, etc. A wide selection of journals (inclusive of 9 subjects, more than 200 journals)

Providing 24-hour high-quality service

User-friendly online submission system

Fair and swift peer-review system

Efficient typesetting and proofreading procedure

Display of the result of downloads and visits, as well as the number of cited articles Maximum dissemination of your research work

Submit your manuscript at: http://papersubmission.scirp.org/

Or contact jbise@scirp.org 